\title{
Children Leading Nonviolent Action for Peaceful Coexistence
}

\author{
Vedabhyas Kundu \\ Programme Officer, Gandhi Smriti and Darshan Samiti, Delhi, India \\ Corresponding author: vedabhyas@gmail.com
}

Received: 14 Jan., 2019

Revised: 03 Apr., 2019

Accepted: 26 May, 2019

\begin{abstract}
A new generation of child leaders across the world are taking up social concerns and working for peace using nonviolent strategies. Right from advocating for climate change concerns to creating awareness on the menace of children marriage and using the symbolism of fasting for peace, the children are not just making impact amongst other young people but also adults. In the $150^{\text {th }}$ birth anniversary of Mahatma Gandhi, it would be apt to capture the efforts of the children and look at how other children can be motivated to join such nonviolent action. This chapter would specifically look at the efforts of four children, Greta Thunberg, Autumn Peltier, PayalJangid and Sajeda Al Sharief and try to assimilate on how their nonviolent action is a reflection of Gandhian nonviolence.
\end{abstract}

Keywords: Nonviolent action, children as leaders, children and nonviolent action, children as peacebuilders

The world will live in peace, only when the individuals composing it make up their minds to do so.

\section{- Mahatma Gandhi}

Gandhi was apt when he said that it was an important responsibility of individuals to work for peace. Unless and until individuals who constitute the world, groups and institutions make a determined bid to ensure peace, the dream of peaceful coexistence will remain a chimera. It is not just adults, but all including youth and children have significant role in contributing towards sustainable peace. More than often adults seem to suggest that children, youth and even women have minimal role to contribute towards a culture of peace. However, some major global initiatives taken up by children in recent times have proved otherwise and is in sync on what Gandhi had underlined on the need of every individuals to work for peace.

The rise of child leaders to take up leadership for environment, mutual coexistence and various other social concerns can be gauged by this message in a placard during a children's march for climate strike,
"You know it is time for change when children act like leaders and leaders act like children." It is in this context, Gandhi had aptly said, "If you want to teach real peace in the world and fight a real war against war, we have to begin with children."

This chapter as a tribute to the Mahatma will try to capture the efforts of children across the world using the powerful tool of nonviolence which according to the apostle of peace is 'an active force of the highest order' and is more powerful than brute force. Children like Greta Thunberg, Autumn Peltier, Payal Jangid and Sajeda Al Sharief have become icons with their efforts spreading like wildfire. Then there are hundreds of Gretas', Autumns', Payals' and Sajedas' in different countries and local communities making deep impact in their societies. It is through stories of some of these children which can be used to motivate other children across the world to encourage sustainable leadership. 


\section{Children leading the Path using Nonviolent Action}

"I believe that the potential of this generation is the realization that they have the power in their hands and with it they can change and bring positive transformation in this world. It is not the question of changing a nation or even a continent; but the entire planet. I believe this is the power of youth. The power to realize that nothing can stop us now. Nothing can prevent us from changing the world!"Cesar Galvez, Child of Nature (The Peace Gong, February 2018 issue).

Cesar Galvez has aptly encapsulated the power of children and young people to bring positive transformation in the world. He is confident that no one can prevent young people in changing the world. The enormous potential of young people and the amazing spirit with which many children across the world are taking up the leaderships reflects the arguments put forward by Cesar.

Soni (February 2018) similarly reflects the statement of Cesar with her profound articulation, "In the purest hearts of the world is the flare of faith to alter the world. In the cleanest souls of the world lies the greatest ability to light this fire with care. For, an army of peace does not need wings of a dove. It needs human limbs which can spread to give and step to move forward. But it is only the tiniest feet which aim for the greatest leaps leaving petite footprints of the collective consciousness of human race."

As Greta Thunberg, the 16-year old nonviolent activist leading a global movement for climate change reached New York, the United Nations in appreciation of her 'mission toward a better world by 2030 greeted her at the Verrazano Narrows Bridge with a flotilla of 17 sailboats. To put the climate crisis in spotlight, Greta travelled from her country, Sweden to reach the United Nations headquarters in New York in a zero-carbon mode of transportation. According to UN News, "Despite the tight quarters and lack of creature comforts, she sailed with her father, a two-man crew and a camera person on the 60-foot Malizia II racing yacht with solar panels and underwater turbines that generated electric power" (https://news.un.org/en/ story/2019/08/1045161).

Greta had launched her nonviolent protest movement in 2018 by protesting outside the Swedish Parliament about the need for immediate action to combat climate change. Initially, there was no support and hardly anyone took notice of her efforts. "She continued to sit in Swedish Parliament with a hand-painted cardboard sign that read 'Skolstrejkförklimatet' (School Strike for the Climate) and would continue to stand there every Friday till the media started taking notice. Slowly but surely her message began to spread. She handed out leaflets that read, "I am doing this because you adults are shitting on my future." With sheer will and determination to make a difference, Thunberg kick-started what would grow into a global campaign for climate action." (https:// www.firstpost.com/tech/news-analysis/how-gretathunberg-mobilised-millions-to-act-on-climateemergency-in-just-a-year-7200831.html)

Ever since then Greta has inspired millions of children and young people across the world to take part in nonviolent climate change strike every Friday. \#Fridays for Future has become synonymous with the powerful nonviolent movement inspired by the 16-year old girl who suffers from Asperger's Syndrome. She has already spoken at major world fora including the United Nations and World Economic Forum.

A discursive analysis of Greta's speeches suggests on how she has been able to construct a new narrative to the climate change crisis and how this is fuelling the largest mass nonviolent action of the $21^{\text {st }}$ century across the globe. For instance, her speech at the World Economic Forum underscores how she has been able to make climate change a critical priority in discourses across the world. She said, "Our house is on fire, I am here to say our house is on fire. According to the IPCC we are less than 12 years away from not being able to undo our mistakes.... Adults keep saying we owe it to the young people to give them hope. But I don't want your hope, I don't want you to be hopeful. I want you to panic, I want you to feel the fear I feel every day. And then 
I want you to act, I want you to act as if you would in a crisis. I want you to act as if the house was on fire, because it is."

Similarly, addressing the COP24 plenary session on December 12, 2018, Greta was equivocal of how politicians lacked the political will to fight climate change, as she noted, "But I've learned that you are never too small to make a difference and if a few children can get headlines all over the world just by not going to school then imagine what we could all do together if we really wanted to...But to do that we have to speak clearly. No matter how uncomfortable that may be. You only speak of a green eternal economic growth because you are too scared of being unpopular. You only talk about moving forward with the same bad ideas that got us into this mess. Even when the only sensible thing to do is pull the emergency brake.... You are not mature enough to tell it like it is. Even that burden you leave to us children." With use of such narratives, Greta has catalysed the children and youth movement for climate change across the world being dominant over efforts of adults which she blames as a bouquet of bad ideas.

Wilson (2019) talking about Greta Thunberg and the power of powerful strategic messaging points out, "Thunberg and the youth movement generally have adopted powerful imagery that conveys complex meanings, with multiple layers, through metaphors and visualizations. The pithy slogan \#FridaysforFuture encapsulates both the action and the reason for action in three short words.

Wilson further notes, "Messaging in the youth movement has also created an identification between the youth climate strikers and the planet itself, as in this sign, proclaiming, "Like the sea level, we rise." This identification has a powerful surface level of meaning - to link the planetary distress reflected in rising sea waters with the rising resistance to global inaction on climate change: "The ice is wearing thin/Just like our patience." To identify youth with the planet is to implicitly charge that the violence being done to the planet is also being done to youth, displacing the "victim" and reproaching adults."

The tenacity of children to be part of the greatest child-led climate change movement in world history has been aptly described by Wilson (2019), At the climate strikes on September 20th in Washington, DC, a father carried his three-and-a-half-year-old daughter on his shoulders, saying, "When she found out she not allowed to go to the climate strike with her two sisters, she called a hunger strike and refused to eat breakfast." Two small girls came to the march in their princess dresses, carrying a sign saying, "Climate Change is Not a Fairy Tale."

Wilson further argues, "The youth movement to combat climate change reverses the usual pattern seen in people power movements, which are often led by adults motivated to make change on behalf of their children's futures. Here the children are shaming the adults for failure of leadership and claiming moral authority."

Meanwhile 13-year old indigenous water advocate from Canada, Autumn Peltier, addressing the UN General Assembly, made a profound observation as she remarked, "Our water deserves to be treated as human, with human rights. We need to acknowledge our waters with personhood, so we can protect our waters." She also mentioned that no child should grow up not knowing what clean water is, or never knowing what running water is. (https://www.cbc.ca/news/canada/autumn-peltierun-water-activist-united-nations-1.4584871)

Autumn further said, "Mr President, we need to work together. Now is the time to warrior up and empower each other to stand for our planet. We need to sustain in the little we have now and develop ways not to pollute the environment and sustain the relationship with Mother Earth and save what we have left," she added. Peltier left the gathered international dignitaries at the UN with this message: "One day I will be an ancestor, and I want my great-grand-children to know I tried hard to fight so they can have clean drinking water."

Analysis of Greta and Autumn's speeches underscores their deep commitment to the interdependent nature of human relationship with nature. When Greta talks about how 'our house is in fire' or when Autumn argues on the need of water to be treated as 'human with human rights', 
the children are taking a cosmocentric view of human beings. This was also the base of Gandhian nonviolence.

Parekh (1997) succinctly explains Gandhian nonviolence in the context of the cosmocentric approach of human beings, "The universe was a common inheritance of all living beings, who were equally entitled to its resources and should live in the spirit of mutual accommodation. Being rational, human beings were the custodian of the rest of the creation and should respect its rights and cherish its diversity." According to the Gandhian praxis, human beings at no right to take more than necessary from the nature as taking more amounted to 'theft'.

Parekh further talking on the Gandhian approach to human interdependence points out, "Since human beings are necessarily interdependent, every human action was both self and other-regarding... when human beings developed themselves, they awakened others to their potentialities and inspired and encouraged, and raised them as well...For Gandhi, human beings could not degrade or brutalize others without degrading or brutalizing themselves, or inflict psychic and moral damage on others without inflicting it on themselves as well."

When Autumn told diplomats at New York City that most people did not think water was alive and had spirit though indigenous people like her believed to be true, she was underscoring how our traditional knowledge and culture believed in the intrinsic link between nature-human-and all other living beings. It also echoed what Gandhi was trying to tell that humankind did not have any right to take anything more from nature other than that was necessary.

Meanwhile, 17-year old Payal Jangid from Rajasthan became the first Indian to receive the Change-maker Award by the Bill and Melinda Gates Foundation for fighting against child marriage. She was conferred with the award for her continuous dedication towards the abolition of child marriage in her village, Hinsla.

According to Payal, her activism and fight to abolish child marriage began at the age of 11, when she had to relent against being married off. She was successful in raising her voice against her parents' decision and prevented the marriage. Talking about the initiatives, she added, "We would organise rallies, posters, paint walls, go house to house, speak to the families. We had to work really hard to make the elders realise that they were prohibiting us from getting our education." As President of her village Bal Panchayat (children's parliament), Payal has taken the lead in conducting a large number of field activities and rallies to empower women and children of her own village and villages nearby.

(https://www.news18.com/news/india/meet17-year-old-payal-jangid-the-first-indian-towin-changemaker-award-for-fighting-childmarriage-2323513.html)

Payal's initiatives to organize protest rallies, promote interpersonal communication by going from house to house are a powerful expression of nonviolent action. Gene Sharp in his book The Politics of Nonviolent Action: Part 2 - The Methods of Nonviolent Action explains the efficacy of protest rallies as a nonviolent action. Nonviolent initiatives for fighting social evils like child marriage have always been important to create awareness in communities.

Mahatma Gandhi was one of the greatest leaders of world history to use fasting as a tool of nonviolent action and persuasion. Meriam (1975) talking of fasting as a form of communication notes, "Of all his techniques of symbolic action, the fast or hunger strike most typified Gandhi's character and temperament. Fasting afforded a method of influencing political policy and social attitudes by creating an emotional impact difficult to achieve through ordinary speech and negotiation. It also provided a source of spiritual renewal for a man dedicated to controlling his senses and desires."

Fasting has been used by many to take up nonviolent struggle. An inspiring effort of using fasting as a tool to propagate peace is by 16-year old Libyan school girl, Sajeda Al Sharief. Sajeda (June 2019) says, "As a 16-year-old, I have been waiting for our seniors to lead us towards peace, respect and humanity. However, I think our seniors are now failing our generation. So, it is time not to sit back 
and wait for the next incident of violence or hatred to happen. It is time for we young people to wake up and take the lead around the world to defeat the forces of hatred and violence. Each one of us are capable of doing this, we have the indomitable spirt and courage to make this world a peaceful place to stay. It is with this conviction that I have decided to act upon and use the power of nonviolent action."

Sajeda has initiated 'Fasting for Peace' in which she and her friends take to fasting every Thursday. On her initiative, Sajeda notes, "I firmly believe that fasting is a powerful tool of nonviolent action. Through fasting, we can draw attention to our concerns. Fasting has a time-honored place in all religious tradition, but it is also a noble strategy in nonviolent change. By observing fast, I firmly believe that we can not only embarrass the forces of hatred using the amazing principles of nonviolence but also coerce them to shun violence. Fasting, to me, is a powerful tool of communication and we are spreading the message of peace and harmony through it."

Sajeda feels children are the worst affected in conflicts and this is the reason that children in such situations should be motivated to take to nonviolent action to voice their concern on violence. Children are taught to just listen and not act but this has to change, she stresses. Fasting for Peace is a powerful strategy of nonviolent communication which is aimed at reaching out to the adults to convince them that they need to stop fighting and instead contribute all their energies for sustainable peace, she adds. According to Sajeda, "Children should make innovative use of different strategies of nonviolent communication to not only bring together their peers in solidarity but also make a strong statement for sustainable peace in their communities and globally."

\section{CONCLUSION}

The efforts of children like Greta, Autumn, Payal and Sajeda to make visible and sustainable impact in today's world reflects a growing trend of children using nonviolent methods to highlight social concerns. These new millennials inspire many other young people to reach out to masses to save humanity from further destruction of conflicts and environmental degradation. Similarly, peace apostles like Gandhi, King and Mandela continue to inspire generations on the efficacy of nonviolent action for lasting peace. The world needs to imbibe the work of these apostles of peace and take leaf from the amazing initiatives of the new kids for a global nonviolent planet.

To conclude, Martin Luther King has rightly said, "If you can't fly then run, if you can't run then walk, if you can't walk then crawl, but whatever you do you have to keep moving forward." The message is clear for children and young people across the world. There is no time left to imbibe a laid-back attitude but to act and keep moving forward for a culture of peace and nonviolence.

\section{REFERENCES}

Al Sharief, Sajeda. 2019. Let's All Fast for Global Peace; The Peace Gong; June 2019.

Merriam, Allen H. 1975. Symbolic Action in India: Gandhi's Nonverbal Persuasion; Quarterly Journal of Speech, 61.

Parekh, Bhikhu. 1997. Gandhi: A Very Short Introduction; Oxford University Press.

Soni, Noopur. 2018. Child of Nature- Building Collective Consciousness of Human Race; The Peace Gong; February, 2018.

Wilson, Elizabeth A. 2019. Greta Thunberg and the Power of Strategic Movement Messaging; https://www.nonviolentconflict.org/blog_post/greta-thunberg-and-the-power-ofstrategic-movement-messaging/?fbclid=IwAR0nN1Xaq6 O2cUV0UmNd5uQhxvDICs1KWRB9wkghxyrWznDD3 nMrdGpN1Yc; retrieved on October 3, 2019. 
